\title{
Replacement Charges for Library Materials
}

Patsy J. Hansel

This is an essay about an article that did not happen. The article, as it turned out, was to be about something that librarians in school, academic and public libraries across North Carolina almost unanimously agree is a nonproblem.

\section{Background and Methodology}

In September 1981 I was asked to write an article dealing with the question of replacement charges to be published in the Summer 1982 issue of North Carolina Libraries. It sounded like a fine topic to me, and since the editors of the issue had given me a full eight months' notice before the deadline, I decided to compose a survey to send to libraries throughout the state to collect some data. Although it is fashionable among our colleagues to insist that we abhor surveys and simply do not have the time to wade through the waves of them that continually lap upon our libraries' shores, I for one almost always enjoy filling them out and I have the idea that most other librarians enjoy them too, or at least are willing to cooperate.

For this proposed study of replacement charges my random sample of libraries did indeed prove cooperative. I mailed 170 surveys (50 to school systems, 50 to academic libraries, and 70 to public libraries) and received 148 completed. The return rate was good, but not quite as good as the numbers indicate, since some school systems returned one survey for the entire system while others returned surveys for a number of schools in the system. The same was true for a few public library systems.

\section{Results of Survey}

To this point, I felt that preparations for the article were going quite well. All I needed to do was (1) compile the data from this hefty stack of surveys and (2) write up the results. While compiling data I detected trouble.

Probably the major underlying assumption of this study was that a significant number of librarians would believe that determining replacement charges for library materials is a very time-consuming procedure, and that they would have come up with some innovative ways of dealing with the problem that would prove instructive to the rest of us. This is not the case. The overwhelming majority of respondents replied that the procedure took hardly any time at allone even stated that no time was involved-and only two librarians from the entire number surveyed indicated that they felt the procedure involved a significant enough application of staff time to bother them. 


\section{Book Prices}

Three librarians apparently had found some part of the procedure irritating enough in the past so that they have resorted to a uniform fee for replacing materials, rather than trying to determine the precise original or current retail price of every item to be replaced. One library bases the uniform fee on the average retail cost in the item's LC area; one charges $\$ 18.00$ for an adult nonfiction book, $\$ 12.00$ for fiction, and $\$ 8.00$ for juvenile; and one charges a uniform fee of $\$ 15.00$ per book.

For replacements, most libraries still charge the retail cost at the time of purchase, which they find on the book card or the shelflist, or try to determine the current retail cost from BIP or another source. Academic libraries are more likely to try to determine the current retail value than to settle for the retail cost at purchase (27 of 34); schools overwhelmingly opt for retail cost at purchase (31 of 40); and public libraries lean a little toward current retail price (36 of 58).

If prices cannot be located by either of the preferred methods, libraries use a variety of approaches. College libraries tend to charge set prices of $\$ 5.00$ to $\$ 15.00$ for a hardbound book and less for paperbacks or just estimate the current value. Schools are more likely to estimate the value of a book for which no price can be located, although a few use set fees. Public libraries also usually estimate the value. In this determination of replacement charges we seem to enter what I keep thinking of as the art and craft of librarianship. Maybe it is one of those things that people keep insisting make us a profession: we think we are competent to make accurate, consistent judgments in this area, and our patrons seem to accept them; or maybe we are just successful in not letting them know how subjective the pricing process is.

Another interesting wrinkle that was evident in this part of the survey is that respondents who mentioned determining prices to charge differ as to whether books gain or lose in value with age. Three college surveys mentioned the problem. Two use the retail price at purchase and add something to it for the replacement cost to the patron (15\% for one, $\$ 1.00$ per decade for the other). One prorates the cost (if the book is 2.5 years old, the patron pays $2 / 3$ of the original price; if it is over 5 years old, $1 / 3$ the original price). Five school libraries Say they cut the price on older books, one stating in very practical terms: "cost minus depreciation." Public libraries that charge the original cost all increase it: "inflate original cost" as one respondent said.

\section{Additional Charges}

As for adding other charges-processing fees, service charges, etc.-to whatever measure libraries use for the base replacement charge, 21 of 34 college libraries do, 20 of 58 public libraries do, and only 4 school libraries do. One public librarian brought up what I think is an important issue, but one that no one else mentioned: this public library charges no additional fees; "since in most cases we get a discount, we feel retail price includes processing, or close enough to it." 
The issue of additional charges is another one of the subjects that bother me but which are apparently non-problems to librarianship at large. I keep think ing that some day some library is going to be questioned on its replacement charges policy, and that it will be on safer ground if its policy emphasizes the added costs of replacing an item rather than the retail price, since the latter is rarely the price a library actually pays. We know that the book which the library owns, has cataloged, classified and processed, actually costs more than the price the library paid for it, or the current retail price. We are not likely to make this fact clear in our policies, however, even when we do have written policies to cover the topic. It seems to me that the reasons explaining why libraries charge to replace materials should be written down for library users as well as for staff. Which brings us to another survey question-why do libraries charge for materials that are not returned? We all have the answer to that question, right? Yes, according to this survey, most of us do have the answer, but the answer is not always the same.

\section{Reasons for Replacement Charges}

Two respondents apparently found the question about replacement charges a little ridiculous. When asked why their libraries charge for replace ment of materials they replied, "Why not?" Other responses dealt with money, responsibility, and deterrence.

Of the college libraries responding to this question, 15 said they charge because they need the money to defray costs of replacement; four libraries said they thought charging would work as a deterrent and get the books back; and four said they charge because it is the patron's responsibility to return items checked out.

Sixteen schools also said they charge because they need the money, but seven said they charge to teach the students responsibility, and thirteen indicated that they charge both to teach responsibility and because they need the money. Only one school mentioned deterrence as a benefit of charging.

Twenty-one public libraries noted that they charge solely to get the money to use to buy replacements; five mentioned teaching responsibility; and four saw charging as a deterrent. Five said they charge because they need the money and see charging as a deterrent; and five others charge because they need the money and see charging as enforcing or teaching responsibility. Two public libraries said they charge because it is the library's responsibility to account for materials bought with public funds, which is a nice twist.

Finally one librarian out of 148 mentioned all three primary reasons for charging: money, deterrence, and responsibility. It seems to me that since he has the distinction of being only one of 148 , he should be noted by name. He is Bob Russell, Director of the Elbert lvey Memorial Library in Hickory.

The results of the why-do-you-charge-for-replacements question also surprised me. Since the primary reason given for charging is that materials budgets need the money, does this really mean that libraries would not charge if 
they all had adequate materials budgets for new items as well as replacements? I had thought libraries charged primarily to try to give people an incentive to return the books, not for the money per se.

\section{Concluding Observations}

I do not think conclusions can be drawn from this data, which is why this is an essay, not an article. I do think that the survey uncovered some interesting facts:

1. Academic libraries tend to try to find the current price of material for which they are charging a patron, while schools are more likely to charge retail cost at purchase. This fact, along with some of the other data, seems to indicate that college libraries feel that books increase in value with age, while school libraries generally are more apt to see their collections as instructional equipment that depreciates with age.

2. College and public libraries are much more likely to add processing or Service charges to the base replacement fee than school libraries are.

3. The majority of public and academic libraries say they charge for replacements because they need the money. Schools agree that they charge because their book budgets need the funds, but a majority mention teaching responsibility as at least a partial reason for charging.

4. Virtually nobody thinks that the time spent in finding the base charge for replacements - whether on a book card, in BIP, or by some other methodis great enough to be concerned about.

According to a March 1982 UPI report of a study conducted at the University of Pennsylvania's Wharton School, "If you want to write for a prestigious academic journal .... study unimportant problems and agree with existing beliefs." My survey indicates that most librarians find my general topic unimportant; however, existing beliefs on the issue are far too varied for me to try to agree with everybody.

Patsy J. Hansel is Assistant Director of the Cumberland County Public Library. 
is an award winning novelist who lives in Raleigh, N.C Her books, for children ages 10-103 are a warm and witry view of growing up and living in communiry.

People who have read her books smile a lor.

\section{YOU CAN ORDER THESE TITLES FOR A GIFT OR A RAINY DAY:}

\section{C/O Arnold's Corners}

Outspoken and independent, young Rosalee finds herself at odds with the rest of Arnold's Corners "Gossip Capital of the World."

\section{What are You Up to, William Thomas?}

William Thomas, master of practical jokes, appears to reform as he plots to humiliate his rival and save Aunt Jessica's business.

\section{Reubella and the Old Focus Home}

With Reubella's help three elderly "young" women transform Shad, N.C. into a new kind of rerirement community.

Send order to:

Address

City

Stare Zip

Date: Amount Enclosed

\begin{tabular}{|c|c|c|c|}
\hline Quantity & Title & Unit Cost & Toral \\
\hline & Arnold's Corners & $\$ 7.95$ & \\
\hline & William Thomas & $\$ 7.95$ & \\
\hline & Reubella & $\$ 7.95$ & \\
\hline & \multirow{4}{*}{$\begin{array}{l}\text { Mail orders to: } \\
\text { Network Ventures, Inc. } \\
\text { P.O. Box } 33614 \\
\text { Raleigh, N.C. } 27606\end{array}$} & Subrotal & \\
\hline & & $\begin{array}{l}10 \% \text { Discount } \\
\text { for } 4 \text { books }\end{array}$ & \\
\hline & & $4 \%$ soles tax & \\
\hline & & $\begin{array}{l}\text { Shipping } \\
\text { S1 per book }\end{array}$ & \\
\hline & & Toral & \\
\hline
\end{tabular}

